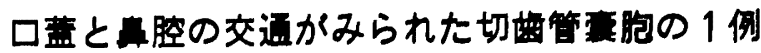

\author{
山猗敬介・池村邦男・河野蘶
}

\section{A case of incisive canal cyst with communication} between the nasal cavity and the hard palate

\author{
Keisuke YAmAsakI - Kunio IkrmurA - Yasutaka Kouno
}

\section{はじめに}

口腔領娀には種々の蒦胞が発現するが，そのなかでも 顔裂性咅胞の占める割合は少ないるのとされている( る). 最近わたくしたちは空粘膜下と口蓋に明らかな交通を 認めた切蒋管烡胞の 1 例を経験したのでその概要を報告 する.

\section{症例}

患 者：【56歳 男性.

初診: 炤和56年 5 月日。

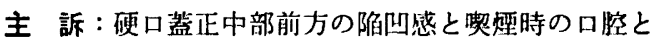
算腔との交通感。

既往歴：昭和54年北九州市内某内科においてて肝硬变の 診断を受け，現在治療を受けている。

家族歴：特記することはない。

現病歴：昭和51年頃硬口蓋正中部前方に限局性の腫脹 を生し，某歯科で切開処置をらけ症状は悢解した。 その 後症状は消失したため放置していた。昭和 56 年 3 月上記 主訴となった 症状を自覚し, 昭和 56 年 5 月当科を受診 した.

現 症：体格は中等度, 栄羔状態は良好で, 顔貌は左 右対称を示し，異常所見は認めなかった，左右の頻下部 には小豆大のリンパ節を各 1 俔触知した。リンパ節の触 診では異常は認められなかった，開口障害はなく，紫牙 は㱝 6 4 本のみが残存していた。硬口盖前方正中部 には約 $3 \times 3 \mathrm{~mm}$ の類円形の陷凹か認められた。同部よ クンンデの捜入が可能であり(写真 1 ), さらに銀線を挿 入すると奥腔側からは認められず口蓋垂後方の咽頭部に

産業医科大学菌科口腔外科

（主任：池村邦男助教授）

Department of Dentistry and Oral Surgery, School of Medicine, University of Occupational and Environmental Health (Chief: Associate Prof. Kunio Ikemura)

受付日：昭和58年1月24日
解比した。

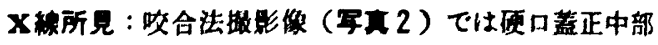

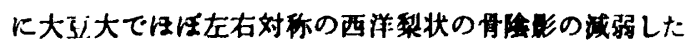

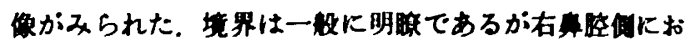
いては一部不明瞪な部分るみられた。 口蓋の陷山部より

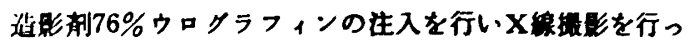

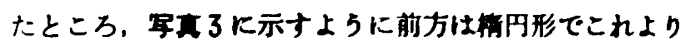

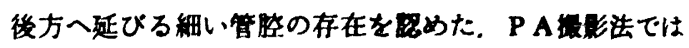
造影都が鼻腔直下の正中部より右の腔底域へ流入して いた（写禹 4 ）。

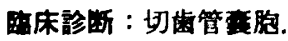

手術およひ绳遗：昭和56年10月日日，局麻下に真胞摘 出術および交通部の閉鎖術を行った，ナなわち陷凹部周 囲に紡鍾形の切開を加え算胸の制淮摘出を行い，これよ

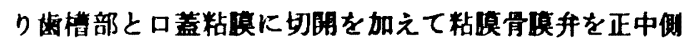
へ移動，父通部の閉鎖を行った（写直 5). 等胞摘出時

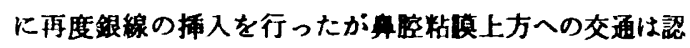
められなかった，交通部の閉鎖後は自覚症状は消失し全 部床拣齿の装着にも支障はなく、彻後10か月を経過した 時点で異常を認めていない（写乘6).

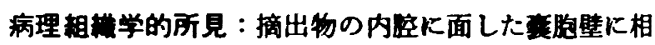
当する部は非常に韭溥な上皮組維を認めたか，扁平上皮 あるいは線毛上皮などの上皮形態の分頼は不可能であっ た。 上皮下には厚い結合組織を認めた（写真 7).

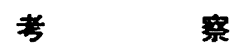

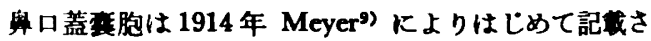
れたといわれる。本症例では硬口蓋前方正中部に病巣を 認め，X線所見では全体に境界明暸な西洋梨状の透過像 とこれより後上方に向か5管腔が存在し，摘出物の組械 摽本で上皮を認めたことなとかから蓋高胞が考えられ

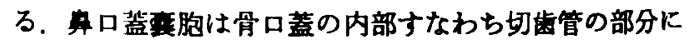
あるもの (切歯管胞), 骨の外部で口蓋の粘膜下にあ

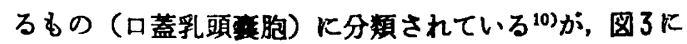
みられるよらに病変は硬口蓋にあることから本症例を切 歯管䓂胞と診断した，本症例と鑑別を要する疾患として

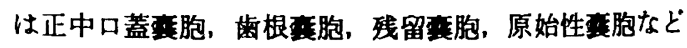


がげられるが上記の所見より他疾蚛は㫴え難い，

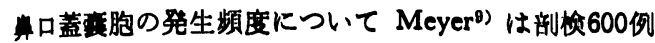

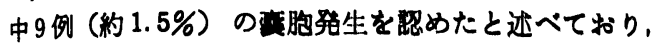
また来院患者のらちの約 $0.45 \%$ といら垠告》ゃ約 $0.2 \%$ といら報告〉すみられた。

本雚胞の発生原因として㯰管の残存上皮の增殖に 上る隻胞化が一般的見解のよ5であり ${ }^{10)}$ ：上皮の增殖の

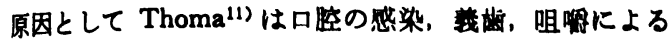

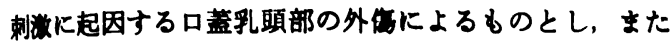
正木 ${ }^{12)}$ は口蓋乳頭に加わった口些からの外伤，中切根 の根尖部に生じた炎症の口蓋管への夏延をあげてい る. 本症例では硬口蓋の萁胞と切齿管を介しての算㓐と の交通があるよらに思われ、このよらな報㑎はきわめて 少なく，このよらな所見を真管の残存と考える人も いる ク，その内面は粘嗼上皮で被われているが出生前後には それぞれの開口部は閉鎖され盲管となり上皮は出生後 1 年ぐらいで消失あるいは痕跡程度になるといわれてい $3^{13)}$ 本症例が前述の蓋管の残存か否かは明らかで はないが興味ある所見と考える。

病理組織学的所見は石川ら ${ }^{10)}$ によれば, 蓋烡胞は 被覆上皮を有する結合組織よりなり，上皮の種類として 扁平上皮，移行上皮，立方上皮，線毛上皮などがあり， 口榕に近いときは扁平上皮であるのが普通であるとして いる. Abrams ${ }^{15)}$ は全61症例の約 $30 \%$ に粘液腺を認めて いる. 本症例では上皮と思われる組織を認めたが上皮の 䝠類は確認できなかった。患者は全部床義歯を使用して おり，義歯の䊒持をよくするため市眅のペースト剂を使 用していたことが上皮成分の脱落または崩壊をきたした のかむしれない.

蓋言胞の処置としては通常口蓋側からの授胞の摘 出, 創の閉鎖が行われる. 本症例の場合これに加えて变 胸の一部が口腔と交通していたので口蓋穿孔閉鎖術に準 した方法を行った．本症例のような小さな口蓋の久損に 対しては，図1に示すよ5に単層の flap である rotating flap, sliding flap, hinge flap, bipedicle flap の応用か; 考えられる. sliding flap は手術操作が容易で浐応頻度 の高い方法であるが，本症例にこの方法を応用した場合 行後齿肉唇移行部を浅くし義歯装着に悪影籍を及ぼすと 考えた. hinge flap は弁の供給部と移動した弁の両側に raw surfase を牫すことになり好ましい方法とは考穴難 い. bipedicle flap は手術侵襲が大きなわりに利点が少 ないよ5に思われた。本症例では rotating flap を選ん だがその理由として，手術操作が比較的簡単であるこ と，口蓋弁は強吸で閉鎖が確実にできることなどがあげ

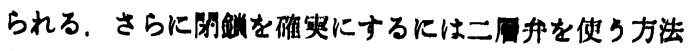

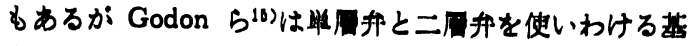

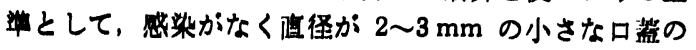

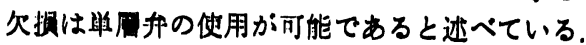

\section{ま}

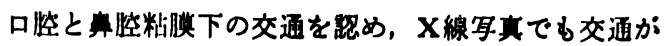
確珰された切管震胞の症例について，その概要を報告 した.

本涌交の政旨は，昭和57年第40回日本口腔外科学会九 州地方会（福岡市）で発表した。

\section{引用文 献}

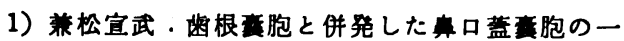
症例. 莐展 42: 7511973.

2）犬山征夫：蓝共胞の一例。耳展 16:727 1973.

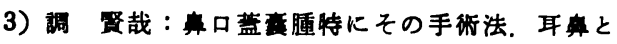
臨床 19: 6331973.

4）踰木 定：颜裂性重胞の病態。 日口外誌 20 : 4331974.

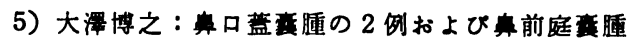
の1例。耳喉 47: 3511975.

6）森 啓充：正中口蓝に発生した非菌原性蕉胞の 3 症例. 日外誌 23: 3081977.

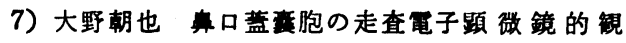
察。 日外誌 27:851 1981.

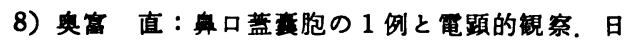
口外誌 27: 18281981.

9) Meyer, A.W.: Median anterior maxillary cysts. J Am Dent Assoc 19: 18511931.

10）石川杬朗, 秋吉正豊編：口腔病理学 II. 永末書 店, 京都, 1977, 853頁.

11) Thoma, K.H.: Oral Pathology. ed 6, Mosby Co, St Louis, 1970, p 459.

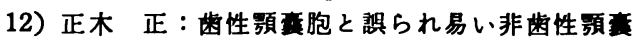

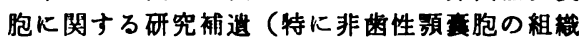
像とその発性機転について）。畨医会誌 37: 2591940.

13）中村平藏編：最新口䧑外科学. 第 2 版, 医菌蒋 出版, 東京, 1977, 596面.

14) Allard, K., et al.: Persisting bilateral nasopalatine duct: A developmental anatomy. Oral Surg 53: 241982.

15) Godon, N.C., Brown, S.L.: Clousure of oronasoantral defects: report of case. J Oral Surg 38: 6001980. 


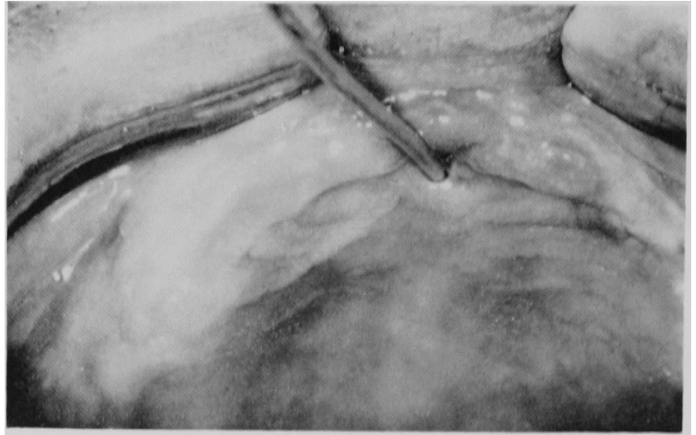

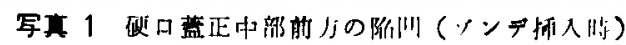

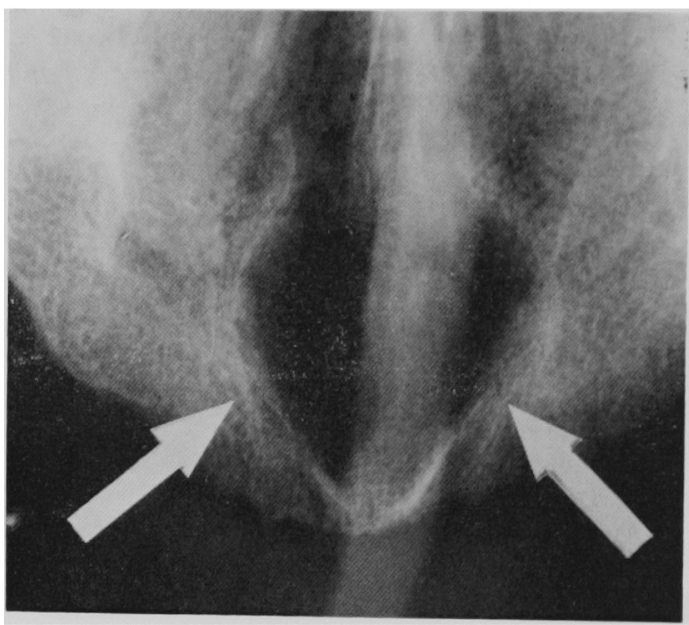

写真 2 硬口蓋正中部の西洋梨形のX線逶過像

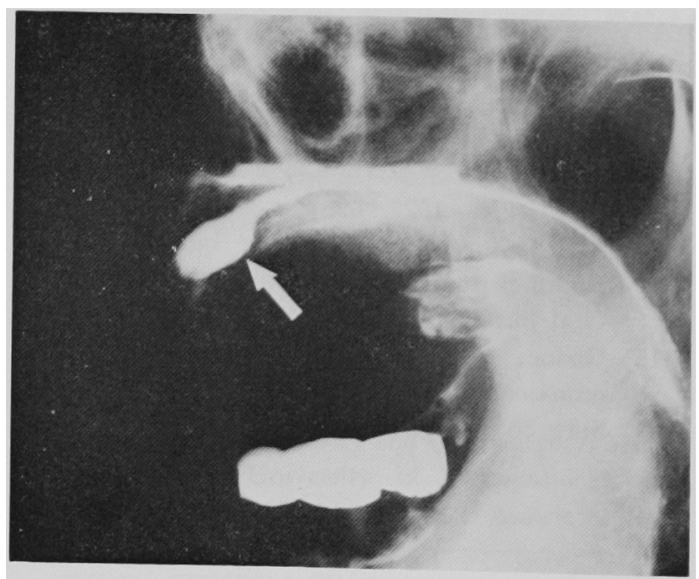

写真 3 造影剤注入後のX線写真

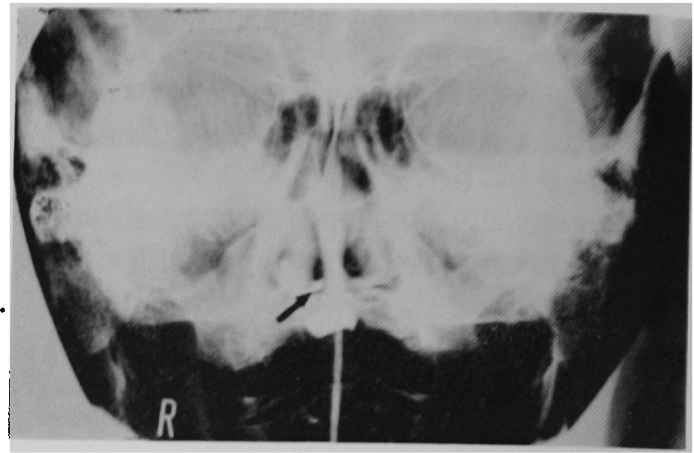

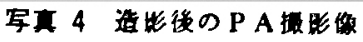

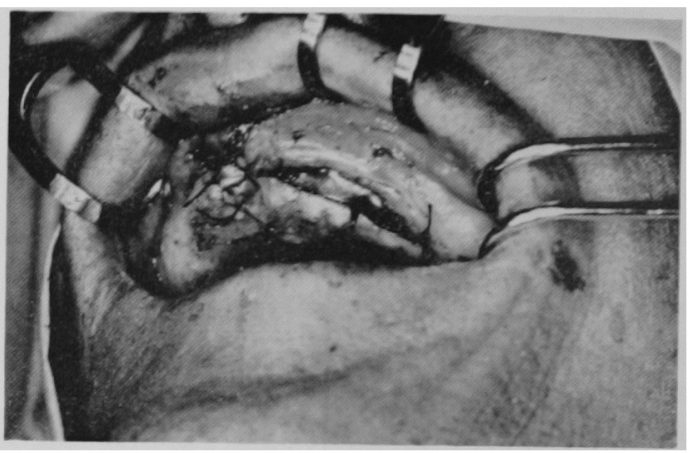

军直 5 手術䊏了時の局所所見

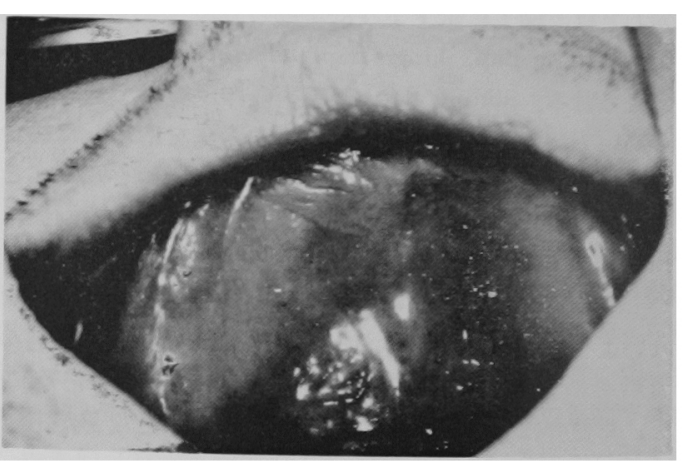

写真 6 徏後 10 只释過後の所見 


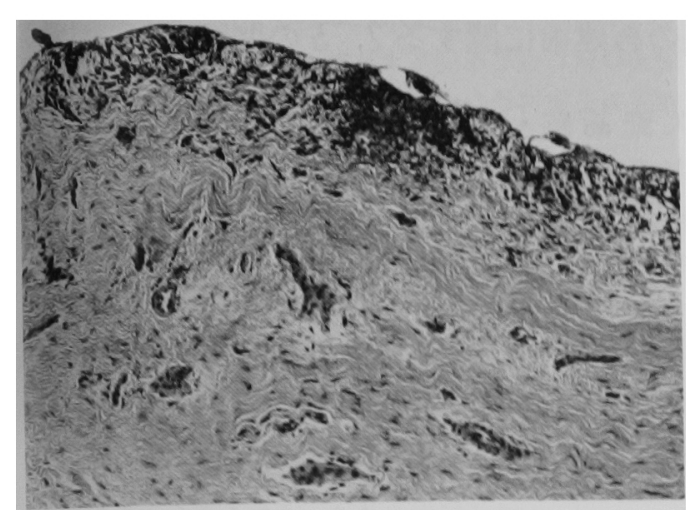

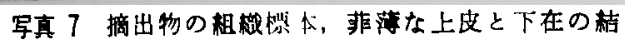
合組戡（H-E 染色， $\times 100 ）$

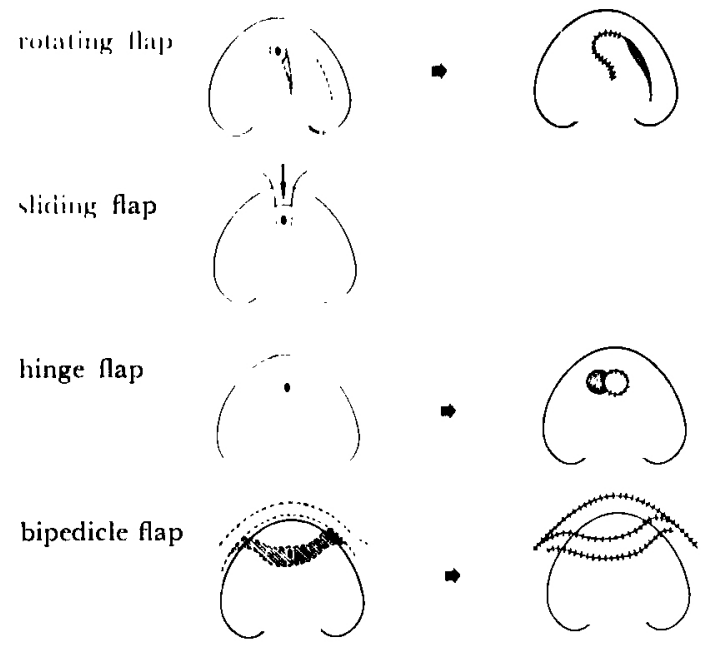

图 1 種々の単凮升を示す（文献15を一部改編） 